precarization in a purely "presentist" light and to understand it as a changing yet constituent part of capitalism since its beginnings.

Peter Birke

Soziologisches Forschungsinstitut Göttingen (SOFI) an der Georg-August-Universität Friedländer Weg 31, 3708 5 Göttingen, Germany E-mail: peter.birke@sofi.uni-goettingen.de

McCann, Bryan. Hard Times in the Marvelous City. From Dictatorship to Democracy in the Favelas of Rio de Janeiro. Duke University Press, Durham [etc.] 20I4. xi, 249 pp. Ill. Maps. \$89.95; £64.00. (Paper: \$24.95; £ 17.99.) doi:10.1017/S0020859015000292

Rio de Janeiro undoubtedly experienced hard times in the r980s, although it would be exaggerated to consider them a "lost decade". The latter expression was coined in the pages of CEPAL Review, the journal of the United Nations Economic Commission for Latin America and the Caribbean, referring to the disastrous macroeconomic performance and outlook for Latin American countries during that period. Yet this does not do justice to the local day-to-day experience of the times, especially not in Rio. For in the cidade maravilhosa - the "marvellous city" - the early i980s also saw a process that preceded and bolstered the transition towards democracy in the country.

As Bryan McCann argues in this book, this process was moved forward in Rio by the grassroots mobilizations of the favela residents, who thus succeeded in gaining official state recognition of their irregular settlements and benefited from massive social programmes. With the economic situation deteriorating and traditional policing methods continuing to prevail, the social reforms fell short of what had been anticipated and, by the end of the decade, criminal organizations had taken over most favela associations. McCann's book demonstrates how the favelas were integrated into the nascent Brazilian democracy and became a recognized part of the city: through a complex process that, far from reducing the distinctions between the favelas and the city, redefined and somehow deepened their separation.

As in his previous book, ${ }^{\mathrm{I}} \mathrm{McC}$ Cann explores re-democratization in Brazil but this time by studying what in Latin American studies had long been a theme for anthropologists, sociologists, and urban planners: urban poverty and its irregular neighbourhoods. Compared with Buenos Aires' villas miserias, Lima's barriadas, or Caracas' barrios, the favelas of Rio were the first to emerge strongly as an object of historical study during the first few years of the twenty-first century. Thus, McCann's work follows the historiographical themes opened up by the work of Alba Zaluar, Marcos Alvito, Maria Lais Pereira da Silva, Lícia do Prado Valladares, Rafael Suares Gonçalves, and Brodwyn Fischer.

Although contemporary to historians, the history of favela life leaves investigators facing constant difficulties: like most subordinate populations, favela inhabitants have left

I. Bryan McCann, The Throes of Democracy: Brazil since 1989 (London, 2008). 
very few formal archives on their practices. McCann states that he had initially intended to conduct his research based mostly on oral history interviews. However, the relative reluctance of interviewees to talk about the rise of trafficker violence in their own neighbourhoods convinced the author to focus his research on written sources and to use his interviews "as a source of background knowledge" (p. I 84).

This methodological choice follows from - or caused perhaps - the definition of the object as the "interactions" (p. 16) between the political leaders within the favelas and the state, its elected officials and civil servants, and non-governmental organizations (NGOs). Thus, McCann's history of the favelas is that of "the nexus that connected the favelas to the rest of the city" (p. I6), which determined where "the strategies of [grassroots] Mobilization and Reform would succeed and where they would fail" (p. I6). This focus enables the author to use NGO archives, reports of public agencies committed to improving the favelas, newsletters published by favela activists, and unpublished masters' theses (mostly by students at the Federal University of Rio de Janeiro) on the social movements of the early I 980 s written by participant observers to construct a study of favela dynamics at the intersection of a bottom-up and a top-down perspective.

McCann's narrative is composed of four sections: "Mobilization", from the late I970s to the state governorship elections of 1982; "Reform", about the socialist Brizola's leftist policy from 1982 to 1985 ; "The Breaking Point", covering the years I985 to I988; and "The Unraveling” of the I990s. The historical narrative begins following a preliminary chapter, "The Big Picture", which sets the scene by outlining the main features of the favelas. McCann tries to do them justice by not being too normative: favelas are neither slums nor squatters' cities, and even though racial and social segregation or informal land tenure rights characterize the condition of favela dwellers, they do not define it in any strict sense. Favelas are defined by their history, a history of self-help housing on hilly and unstable terrains irregularly divided into plots for an informal real estate market.

In Chapter 2 McCann relates the mobilization of a new favela movement led by a new generation of favela activists influenced by the Pastoral das Favelas, an office of the Archdiocese of Rio de Janeiro strongly inspired by principles of liberation theology. During the late I970s the movement grew, based on the successes of the Pastoral in preventing favela removals. Such mobilizations changed the face of favela organizations in Rio and their attitude towards the municipality and Rio state officials. The compromises of the "politics of the water spigot", personified by state governor Antônio de Pádua Chagas Freitas, when favela association leaders traded political support for basic infrastructural improvement, had become insufficient. The leaders of the new favela movement demanded security of tenure as a right, fostering community politics and awareness raising among the favelados, the local residents. In 1982 they eventually supported the charismatic socialist candidate Leonel Brizola in the Rio state governorship elections, strongly contributing to his victory against the candidate put forward by the military regime. In the run-up to the elections, Brizola had founded a new party, the Partido Trabalhista Brasileiro (PTB, Brazilian Workers' Party), designed to attract the votes of the favelados by opportunely "craft[ing] a broader conception of the Brazilian working class, one defined more by place of residence - in the favelas [...] - than by employment” (p. 69).

Using the archives of the Pastoral and the archives of Rio State, among other sources, McCann demonstrates convincingly how the favela movement changed the fundamental 
orientation of favela politics and played a key role in transforming the electoral agenda of Rio State into a breakthrough for re-democratization. This led to Brizola's policy of reform as Rio governor, starting from 1983 , which is described in Chapter 3. The author depicts the implementation of Brizola's socialismo moreno, or "brown socialism", towards the favelas as constituting a radical reorganization of public policies. These brought real infrastructural improvements to neighbourhoods that lacked basic amenities.

McCann focuses especially on three major lines of reform - land titling, public education, and public security - which proved to be both innovative and incomplete, if not a failure. The land-titling process did not interest favela dwellers as the state had already declared an end to removals. Fostering preventive practices among the state police did not immediately bear much fruit either, as officers were used to being entirely repressive and prone to criminalize favela dwellers. Likewise, the ambitious public education plan, put into action with the opening of many new model schools, did not achieve its objectives (though it represented definite progress for favela schooling). Association leaders became official middlemen for all these policies. Indeed, with the Municipal Secretariat for Social Development Brizola created a "parallel administration" (p. 79) within municipal government specifically dedicated to favela governance by hiring locals as staff. According to McCann, the Secretariat became the canal for Brizola's political patronage as well as a genuine merit-based social elevator for favela residents. Thus, favela associations became "the conduits for public investment" (p. 8I) and increasingly lost their ability to represent local demands.

In Chapter 4, "The Breaking Point", McCann relates how both Brizola's radical reforms and the favela movement of the late i970s lost their momentum in the second half of the i 980 s. While national re-democratization was validated by the presidential elections of 1985 , hyperinflation, drug trafficking, and police abuses actually jeopardized the rights of the favelados. The narrative here becomes one of expanding drug trafficking in the favelas. McCann demonstrates how local traffickers established control over favela associations by using violence, largesse, and by exploiting popular hatred towards the police. Because public administration used the associations as key instruments in its favela politics, traffickers took over this instrumentalization for their own benefit. The repression of drug trafficking thus became politically costly for officials, while it also became extremely dangerous for association leaders to contest the supremacy of traffickers. The situation became catastrophic when, in 1988, after disastrous landslides in various favelas, the mayor of Rio declared the municipality bankrupt and terminated all social programmes.

The short Chapter 5, "The Unraveling", gives a gloomy picture of life in the favelas during the I990s, where residents faced daily violence at the hands of corrupt police officers and traffickers. In his Epilogue, McCann ultimately highlights some of Brizola's reforms as the first steps towards improving the favela security achieved over recent years. He points particularly to Carlos Magno Nazareth Cerqueira, leader of the attempt to reform the police, as the one who inspired a new generation of officers.

Bryan McCann offers a compelling history of re-democratization in Rio de Janeiro throughout the I980s. His vivid account places the evolution of the favelas at the centre of multiple histories: those of grassroots mobilizations, criminal networks and practices, police culture, and party politics. For a comprehensive immersion in one of these distinctive but articulated realities, one would still have to consult monographs or anthropological works. Nonetheless, McCann's contribution is a stimulating and enlightening reconstitution 
of the historical drama in which all these developments unfolded and recreated the separation between the favelas and the rest of the city.

\section{Serge Ollivier}

Mondes Américains UMR 8168, Université Paris I Panthéon-Sorbonne 17, rue de la Sorbonne, 7523 I Paris Cédex 05, France E-mail: srg.ollivier@gmail.com 